\title{
Survival and growth of globemallow [Sphaeralcea] species in dry land spaced-plant nurseries
}

\author{
BRUCE M. PENDERY AND MELVIN D. RUMBAUGH
}

\section{Abstract}

Globemallows (Sphaeralcea spp.) have potential in rangeland seedings. Thirty-seven accessions of globemallow were grown at 2 sites in northern Utah and southern Idaho to quantify their agronomic attributes. Data for transplant survival, standing crop, and seed yield were collected in 1987 and 1988 . Total globemallow survival (mean $=92 \%$ ) and seed weights (mean $=0.8 \mathrm{~g} / \mathrm{plant}$ ) differed significantly $(P \leq 0.05)$ among locations. Plant weight (mean $=102 \mathrm{~g} /$ plant) differed significantly $(P \leq 0.05)$ among locations, species (S. grossulariifolia, $S$. coccinea, $S$. parvifolia, $S$. munroana, and interspeciffc hybrids), and years. In a second study, 5 globemallow accessions of 2 species and 'Spredor 2' alfalifa (Medicago sativa) were grown with 'Hycrest' crested wheatgrass (A gropyron desertorum $\times$ A. cristatum) to determine forage yields from 1985-1988. Globemallows produced significantly $(P \leq 0.05)$ less forage $\left(62 \mathrm{~g} / \mathrm{m}^{2}\right)$ than alfalfa $\left(389 \mathrm{~g} / \mathrm{m}^{2}\right)$. Forage yield of $S$. munroana $\left(76 \mathrm{~g} / \mathrm{m}^{2}\right)$ did not differ significantly $(P>0.05)$ from that of $S$. grossulariifolia $\left(48 \mathrm{~g} / \mathrm{m}^{2}\right)$. Forage yield of crested wheatgrass $\left(\right.$ mean $\left.=101 \mathrm{~g} / \mathrm{m}^{2}\right)$ did not differ significantly $(P>0.05)$ when grown with globemallow versus alfalfa. Plant breeding and selection could probably improve these agronomic attributes for globemallows seeded on rangelands.

Key Words: globemallow, Sphaeralcea, Malvaceae, forage yield, plant breeding, range seeding

Globemallows (Malvaceae: Sphaeralcea) are native forbs found in the western U.S.A. They are cool-season perennials that are best adapted to open or disturbed habitats in areas that receive 200 to $350 \mathrm{~mm}$ precipitation annually (Wasser 1982, Stevens et al. 1985). The taxonomy, reproduction, and possible evolution of globemallows have been described by Kearney (1935), Jefferies (1972), Welsh et al. (1987), and Rumbaugh et al. (1989). Interspecific hybridization and self-sterility are common. Other ecological, nutritional and management factors were discussed by Pendery and Rumbaugh (1986) and Horton (1989).

Globemallows have fair to good palatability for big game and sheep and may be useful for mined land reclamation (Wasser 1982, Stevens et al. 1985, Uresk and Yamamoto 1986). Therefore, globemallows have potential as a forb component in rangeland seedings. Plant breeding and selection, however, could probably improve agronomic attributes of seeded globemallows. Unfortunately, baseline information on which to develop a selection program is not available.

The objectives of this study were to: (1) characterize agronomic attributes of 37 accessions of globemallow, and (2) to quantify forage yield of 5 accessions of globemallow grown with 'Hycrest' crested wheatgrass (Agropyron desertorum Fisch. ex (Link) Schult. $X$ A. cristatum (L.) Gaertn.).

\footnotetext{
Authors are range scientist and research geneticist, USDA-ARS, Forage and Range Laboratory, Utah State University, Logan 84322-6300.

The research is a contribution from the USDA-ARS and Utah Agricultural Experiment Station, Logan. Journal paper 3848.

We thank Mario Figueroa, Uta Rosenburger, Hossein Moazami, and John Letter for help in conducting the field work.

Manuscript accepted 10 January 1990.
}

\section{Materials and Methods}

\section{Study Sites}

The studies were conducted in Cache Valley near Logan, Utah $\left(41^{\circ} 45^{\prime} \mathrm{N}, 111^{\circ} 48^{\prime} \mathrm{W}, 1,389 \mathrm{~m}\right)$ and Curlew Valley near Stone, Idaho $\left(41^{\circ} 57^{\prime} \mathrm{N}, 112^{\circ} 42^{\prime} \mathrm{W}, 1,411 \mathrm{~m}\right)$. Average precipitation and temperature based on 28 years of records are $471 \mathrm{~mm}$ and $7.4^{\circ} \mathrm{C}$ in Cache Valley. Average precipitation and temperature for 26 years are $321 \mathrm{~mm}$ and $7.4^{\circ} \mathrm{C}$ in Curlew Valley. Soil at the Cache Valley site is a Nibley silt clay loam (Aquic Argiustoll), and at the Curlew Valley site soil is a Hansel silt loam (Xerollic Haplargid).

\section{Agronomic Attributes Study}

Seeds of 37 accessions of globemallow were obtained in 1985 or 1986 from Arizona (1), California (1), Colorado (1), Idaho (2), Nevada (2), Utah (26), and Wyoming (4). The accessions represented 3 interspecific hybrids (S. parvifolia $\times S$. grossulariifolia) and 4 species: $S$. munroana (Dougl.) Spach in Gray (7); S. grossulariifolia (H.\&A.) Rydb. (6); S. parvifolia A. Nels. (17); and S. coccinea (Nutt.) Rydb. (4). Nomenclature follows Welsh et al. (1987).

Seeds were scarified with sandpaper to enhance germination (Sabo et al. 1979, Roth et al. 1987). Plants were grown in $150 \mathrm{~cm}^{3}$ cones (soil was 4 parts sand:2 peat moss: 1 vermiculite) in the greenhouse during fall and winter 1986-1987. Entries were transplanted into clean-tilled dry land nurseries in Curlew Valley and Cache Valley on 12 April 1987 and 23 April 1987, respectively. A 10-replicate randomized complete block experimental design was used at each location. Plots contained 2 plants of an accession spaced $0.5 \mathrm{~m}$ apart with $1.5 \mathrm{~m}$ between block rows. Data were collected in 1987 and 1988.

Survival was scored in the spring and fall each year. Plants were considered alive if they had green leaves and stems and dead if there was not green foliage. Percent survival was then calculated from the scores for 4 time periods: summer 1987, winter 1987-1988, summer 1988 and study-long.

Standing crop attributes that we measured were number of primary basal stems, maximum stem length, subjective leafiness scores, and season-long plant weights. Primary basal stems were defined as the large stems originating from the crown, most of which developed an inflorescence. Maximum stem length was measured for the longest primary basal stem on a plant. Leafiness scores consisted of 2 components, leaf size and number, that were rated low, moderate or high. Thus, there were 9 possible leafiness scores, ranging from plants with few small leaves to those with many large leaves. Plants were harvested individually on 12 dates from 31 July to 18 September 1987 . Individual plant sampling was done to maximize seed and forage yields among these phenologically asynchronous entries. Only 1 harvest per plot was possible in 1987. Two harvests per plot were possible in 1988: the first occurred on 6 dates from 28 June to 25 July, the second was done 19 September to 22 September. Plant samples were dried in greenhouses at about $32^{\circ} \mathrm{C}$. Season-long plant weights were calculated as the sum of the individual harvest dry-weights.

Seed yield and phenology attributes that we measured were day 
Table 1. Mean (min.-max) survival of globemallows (Sphaeralcey) at 2 locations in northern Utah and southern Idaho. Minimuan and maximum values represent the range of accesion means.

\begin{tabular}{|c|c|c|c|c|}
\hline \multirow[b]{2}{*}{ Source } & \multicolumn{4}{|c|}{ Survivall } \\
\hline & Summer 1987 & Winter 1987-1988 & Summer 1988 & Total \\
\hline $\begin{array}{l}\text { Location } \\
\text { Cache Valley, Utah } \\
\text { Curlew Valley, Idaho }\end{array}$ & $96 a^{2}(60-100)$ & $\begin{array}{l}95 \mathrm{a}(60-100) \\
96 \mathrm{a}(74-100)\end{array}$ & $96 \mathrm{a}(82-100)$ & $\begin{array}{l}89 \mathrm{a}(40-100) \\
94 \mathrm{~b}(93-100)\end{array}$ \\
\hline $\begin{array}{l}\text { Species } \\
\text { S. coccinea } \\
\text { S. parvifolia } \\
\text { S. munroana } \\
\text { S. grossulariifolia } \\
\text { Hybrid }\end{array}$ & $\begin{array}{l}97 a(96-100) \\
99 a(93-100) \\
98 a(94-100) \\
97 a(87-100) \\
97 a(94-100)\end{array}$ & $\begin{array}{l}89 a(81-100) \\
95 b(78-100) \\
99 b(96-100) \\
97 b(92-100) \\
98 b(93-100)\end{array}$ & $\begin{array}{l}98 \mathrm{a}(95-100) \\
98 \mathrm{a}(95-100) \\
97 \mathrm{a}(93-100) \\
99 \mathrm{a}(94-100) \\
98 \mathrm{a}(96-100)\end{array}$ & $\begin{array}{l}86 a(78-100) \\
92 a(71-100) \\
95 a(87-100) \\
94 a(80-100) \\
92 a(86-97)\end{array}$ \\
\hline
\end{tabular}

'Summer 1987 survival: 23 April 1987 to 17 September 1987 in Cache Valley and 12 April 1987 to 18 September 1987 in Curlew Valley. Winter $1987-1988$ survival: 18 September 1987 to 10 May 1988 in Cache Valley and 19 September 1987 to 11 May 1988 in Curlew Valley. Summer 1988 survival: 11 May 1988 to 20 September 1988 in Cache Valley and 12 May 1988 to 28 September 1988 in Curlew Valley.

${ }^{2}$ Within a survival class and source of variation, means with different letters differ significantly (LSD 0 ).

of year on which the first flower opened fully, estimated percent of schizocarps (the fruit or "globe") ripe when a plant was harvested and seed weights. Date of first flower was determined 3 times weekly, May-September. Estimates of the percent of schizocarps ripe were made for the 1987 and first 1988 harvests, but not the second 1988 harvest because a second seed crop had not matured by that time. Air-dried plant samples were threshed by hand and seed weights obtained.

Residual herbicide (Simazine) from a previous study affected growth of $10 \%$ of the plants in Cache Valley. Entries were affected randomly in portions of 9 blocks. Herbicide-affected plants (obvious because of their chlorotic leaves) were dropped from analyses and the data were analyzed as a completely random design with a random effects model (Winer 1962).

\section{Forage Yield Study}

Two $S$. munroana and $3 S$. grossulariifolia accessions included in the above study were seeded individually with 'Hycrest' crested wheatgrass at the same locations to measure forage yield. Plots were not irrigated. 'Spredor 2' alfalfa (Medicago sativa L.) was seeded with the grass as a control treatment. Globemallow and alfalfa seeds were scarified with sandpaper and alfalfa seeds were dusted with a commercial Rhizobium inoculant.

Clean-tilled plots were seeded with a 3:1 grass:forb mixture (weight/weight basis) at a rate of $5.6 \mathrm{~kg} / \mathrm{ha}$ pure live seed. Plots were seeded on 18 April 1985 and 23 April 1985 at Curlew Valley and Cache Valley, respectively. Plots were $8 \mathrm{~m}$ by $1 \mathrm{~m}$ with 4 rows per plot. Rows in plots were $25-\mathrm{cm}$ apart. Crested wheatgrass borders were seeded on the periphery of the experiments. A 3replicate randomized complete block experimental design was used at each location. Data were collected 1985 to 1988.

Six meters of the inner 2 rows of each plot were clipped 3 times annually to 5-cm height when about one-tenth of the globemallows were blooming. Forb (globemallow or alfalfa) and grass components were sampled separately and dried in a forced-air oven at $60^{\circ}$ C. Season-long forage yields are reported. The number of $15-\mathrm{cm}$ gaps in the stands were measured and used as a covariate to adjust for unequal stand establishment (Kramer and Davis 1949). Linear contrasts and the least significant difference test (LSD) were used to determine which means differed significantly $(\alpha=0.05)$.

\section{Results and Discussion}

\section{Agronomic Attributes Study}

\section{Transplant Survival}

Survival was significantly lower in Cache Valley than in Curlew Valley both summers but was still high at both locations (Table 1). The range among accession means for summer survival was greater in Cache Valley than in Curlew Valley. Survival did not differ significantly among species either summer. The species were well adapted to the dry summer conditions that prevail at the study sites (Table 2).

Table 2. Total annual precipitation and average annual temperatures at the recording stations nearest the study sites.

\begin{tabular}{|c|c|c|c|c|}
\hline \multirow[b]{2}{*}{ Year } & \multicolumn{2}{|c|}{ Cache Valley } & \multicolumn{2}{|c|}{ Curlew Valley } \\
\hline & Precipitation & Temperature & Precipitation & Temperature \\
\hline $\begin{array}{l}1985 \\
1986 \\
1987 \\
1988\end{array}$ & $\begin{array}{c}-m m--- \\
490 \\
718 \\
426 \\
288\end{array}$ & $\begin{array}{c}{ }^{\circ} \mathrm{C} \\
5.3 \\
8.3 \\
7.7 \\
7.7\end{array}$ & $\begin{array}{c}-\operatorname{mm}=-\cdots \\
379 \\
313 \\
367 \\
192\end{array}$ & $\begin{array}{c}0 . \mathrm{C} \\
6.4 \\
8.1 \\
8.5 \\
7.4\end{array}$ \\
\hline
\end{tabular}

Winter survival did not differ significantly among locations but differences among species were significant (Table 1). S. coccinea had significantly lower survival than the average survival of the other species. $S$. coccinea is morphologically distinct from the other species that were studied: it is often rhizomatous and its inflorescence is racemose whereas the other species have a thrysoid inflorescence (Jefferies 1972, Welsh et al. 1987). S. coccinea may also have physiological differences from the other species that affect winter survival. An entry of $S$. parvifolia from southern Utah had the lowest individual entry winter survival, $78 \%$. This could have been due to poorer adaptation to colder climatic conditions in northern Utah.

Total survival was significantly lower in Cache Valley than in Curlew Valley, but was high at both locations (Table 1). The range among accession means for total survival was greater in Cache Valley than in Curlew Valley. Total survival did not differ significantly among species. The accession of $S$. parvifolia from southern Utah mentioned above also had the lowest individual entry total survival, $71 \%$.

Survival of naturally occurring $S$. grossulariifolia cohorts in western Utah averaged $47 \%$ during the first 2 years of a previous study but was $2 \%$ after 34 years (West 1979). Howe and Wright (1986) found $24.5 \%$ mortality after 1 year for $S$. ambigua in the Mojave Desert in California. We believe high survival in our study relative to studies done under natural conditions was due to establishment by transplanting rather than by direct seeding. Of course, most rangeland plantings are established by seeding.

\section{Standing Crop}

Plant weights differed significantly among locations, species, and years (Table 3). Plants produced 9.8 times more biomass in 
Table 3. Mean (min.-max.) standing crop and seed yield of globemallows (Sphaeralcea) at 2 locations in northern Utah and southern Idaho, 1987 to 1988. Minimum and maximum values represent the range of accession means.

\begin{tabular}{|c|c|c|c|c|c|c|c|}
\hline \multirow[b]{2}{*}{ Source } & \multicolumn{4}{|c|}{ Standing Crop } & \multicolumn{3}{|c|}{ Seed Yield } \\
\hline & Plant weight & Stems & $\begin{array}{l}\text { Maximum stem } \\
\text { length }\end{array}$ & Leafiness & First flower & $\begin{array}{l}\text { Schizocarps } \\
\text { ripe }\end{array}$ & Weight \\
\hline Location & $-g /$ plant- & -no.- & $--\mathrm{cm}-$ & - scorel - & - day of year - & $\cdots \%=$ & - g/plant - \\
\hline $\begin{array}{l}\text { Cache Valley, Utah } \\
\text { Curlew Valley, Idaho }\end{array}$ & $\begin{array}{r}205 \mathrm{a}^{2}(26-376) \\
21 \mathrm{~b}(4-41)\end{array}$ & $\begin{array}{r}27 a(16-38) \\
8 b(3-13)\end{array}$ & $\begin{array}{l}59 \mathrm{a}(17-80) \\
26 \mathrm{~b}(7-42)\end{array}$ & $\begin{array}{l}3.6 \mathrm{a}(2.1-4.3) \\
1.4 \mathrm{~b}(1.0-1.8)\end{array}$ & $\begin{array}{l}160 \mathrm{a}(152-170) \\
178 \mathrm{~b}(166-197)\end{array}$ & $\begin{array}{l}42 \mathrm{a}(22-59) \\
28 \mathrm{a}(3-50)\end{array}$ & $\begin{array}{l}1.4 a(0.1-3.2) \\
0.2 b(0-0.6)\end{array}$ \\
\hline $\begin{array}{l}\text { Species } \\
\text { S. coccinea } \\
\text { S. parvifolia } \\
\text { S. munroana } \\
\text { S. grossulariffolia } \\
\text { Hybrid }\end{array}$ & $\begin{array}{r}33 a(14-42) \\
114 b(82-139) \\
102 b(83-138) \\
109 b(64-188) \\
113 b(92-144)\end{array}$ & $\begin{array}{l}13 \mathrm{a}(10-17) \\
17 \mathrm{a}(10-23) \\
18 \mathrm{a}(16-19) \\
17 \mathrm{a}(15-22) \\
15 \mathrm{a}(11-18)\end{array}$ & $\begin{array}{l}19 \mathrm{a}(12-23) \\
47 \mathrm{bc}(12-55) \\
35 \mathrm{~b}(25-44) \\
39 \mathrm{bc}(33-46) \\
50 \mathrm{c}(42-58)\end{array}$ & $\begin{array}{l}1.9 \mathrm{a}(1.5-2.1) \\
2.4 \mathrm{~b}(1.5-2.7) \\
2.4 \mathrm{~b}(2.1-2.8) \\
2.5 \mathrm{~b}(2.1-2.8) \\
2.6 \mathrm{~b}(2.2-2.9)\end{array}$ & $\begin{array}{l}174 a(171-178) \\
169 a(162-181) \\
169 a(164-174) \\
170 a(166-173) \\
168 a(166-172)\end{array}$ & $\begin{array}{l}15 a(9-19) \\
39 b(32-53) \\
33 b(29-40) \\
32 b(28-39) \\
38 b(32-47)\end{array}$ & $\begin{array}{l}0.1 \mathrm{a}(0-0.1) \\
0.9 \mathrm{a}(0.4-1.5) \\
0.6 \mathrm{a}(0.4-1.0) \\
0.7 \mathrm{a}(0.2-1.1) \\
1.1 \mathrm{a}(0.8-1.5)\end{array}$ \\
\hline $\begin{array}{l}\text { Year } \\
1987 \\
1988\end{array}$ & $\begin{array}{r}54 a(12-114) \\
142 b(16-257)\end{array}$ & $\begin{array}{c}5 a(3-8) \\
26 b(15-36)\end{array}$ & $\begin{array}{l}37 a(9-58) \\
44 b(14-58)\end{array}$ & $\begin{array}{l}2.1 \mathrm{a}(1.5-2.8) \\
2.6 \mathrm{~b}(1.6-3.2)\end{array}$ & $\begin{array}{l}195 \mathrm{a}(178-214) \\
148 \mathrm{~b}(142-156)\end{array}$ & $\begin{array}{l}36 a(11-59) \\
32 a(6-50)\end{array}$ & $\begin{array}{l}0.6 \mathrm{a}(0.1-1.1) \\
0.9 \mathrm{a}(0-2.2)\end{array}$ \\
\hline
\end{tabular}

11 = few, small leaves.

2 = few leaves of moderate size, or moderate number of small leaves.

$3=$ moderate number and sized leaves.

4 = many moderate sized leaves, or moderate number of large leaves.

$5=$ many, large leaves.

2Within an attribute and source of variation, means with different letters differ significantly (LSD 0.05 ).

Cache Valley than in Curlew Valley. The range among accession means was also greater in Cache Valley than in Curlew Valley. Higher values of most attributes that we measured in Cache Valley than in Curlew Valley may have been due to less competition since survival was lower in Cache Valley. However, higher attribute values in Cache Valley were most likely due to greater precipitation (Table 2). S. coccinea plants weighed significantly less than the average of the other species. One accession of $S$. coccinea at the Cache Valley site spread by rhizomes, a desirable trait for rangeland seeding and reclamation. $S$. grossulariifolia had the greatest range among accession means for plant weight. An entry of $S$. grossulariifolia collected within $10 \mathrm{~km}$ of the Cache Valley site had the greatest average weight, $188 \mathrm{~g} /$ plant. Globemallows produced 2.6 times more biomass in 1988 than in 1987 despite less precipitation in 1988 (Tables 2 and 3). Apparently, at least 2 years are required for globemallows to reach full size. The range among accession means for plant weights was greater in 1988 than in 1987.

Stem number differed significantly among locations and years but not among species (Table 3). Maximum stem length differed significantly among locations, species, and years. The range among accession means for stem number and length were also greater in Cache Valley than in Curlew Valley. S. coccinea had significantly shorter stems than the mean of the other species. S. parvifolia had the greatest range in accession means for primary stem number and length. Two accessions of $S$. parvifolia, one from southern Utah and the other from Nevada, had the greatest average number of stems, 23. A hybrid collected in southern Utah had the longest stems on average, $58 \mathrm{~cm}$. Plants had 5.2 times as many stems in 1988 as in 1987 . Stem length was $16 \%$ greater in 1988 than in 1987.

Plants in Cache Valley were significantly leafier than in Curlew Valley (Table 3). The range among accession means for leafiness was also greater in Cache Valley than in Curlew Valley. Species also differed significantly in leafiness scores. $S$. coccinea had significantly fewer, smaller leaves than the mean of the other species. $S$. parvifolia had the greatest range among accession means for leafiness scores. A hybrid from southern Utah had the highest average leafiness score, 2.9. Plants were significantly leafier in 1988 than in 1987. The range among accession means for leafiness was greater in 1988 than in 1987. Some accessions of globemallow are quite leafy and large and have potential as forage plants. However, the palat- ability and nutritional value of these accessions need to be evaluated.

\section{Seed Yield and Phenology}

The day of year on which the first flower on a plant was fully open differed significantly among locations and years but not among species (Table 3). Plants flowered 18 days earlier in Cache Valley than in Curlew Valley ( 9 June versus 27 June). The range among accession means for date of first flower was greater in Curlew Valley than in Cache Valley. An accession of $S$. parvifolia collected in southern Utah had the earliest date of first flower, 11 June. Plants flowered 1.5 months earlier in 1988 than in 1987 (about 1 June versus 15 July). Plants could invest resources in reproduction earlier in 1988 than in 1987 since the plants were well established in 1988. Drier conditions in 1988 also could have caused earlier flowering.

Hewitt (1980) found that naturally occurring $S$. coccinea near Billings, Mont., flowered 20 May 1977 and 8 June 1978. Ackerman et al. (1980) reported that $S$. ambigua flowered from late April to 1 May in the Mojave Desert and in transitional areas from the Mojave to the Great Basin. They believed that phenological events were primarily triggered by rainfall and temperature, and secondarily by photoperiod.

The estimated percent of schizocarps ripe at harvest differed significantly among species but not among locations or years (Table 3). S. coccinea had a significantly lower percentage of schizocarps ripe at harvest than the average of the other species. The flowers on $S$. coccinea often failed to develop a globe, or the globes dropped off a plant before they ripened. S. parvifolia had the greatest range among accession means for percent of schizocarps ripe. The accession of $S$. parvifolia mentioned above that had the earliest date of first flower also had the greatest percent of schizocarps ripe at harvest, $53 \%$.

Plants produced one-seventh as much seed in Curlew Valley as they did in Cache Valley, probably due to lower precipitation in Curlew Valley (Tables 2 and 3). The range among accession means for seed weights was greater in Cache Valley than in Curlew Valley. Seed weights did not differ significantly among species. Obviously these data were highly variable. Two accessions of $S$. parvifolia and a hybrid had the greatest seed yields, $1.5 \mathrm{~g} / \mathrm{plant}$. Seed weights also did not differ significantly among years. While plants were larger in 
1988 than in 1987 , and flowered earlier in 1988 than in 1987, there was not a concomitant increase in seed weights, or in seed ripeness as judged by the percent of schizocarps ripe.

Indeterminant flowering and seed set are barriers to commercial production of globemallow seed (Stevens et al. 1985, Roth et al. 1987). However, there appears to be sufficient variation in these traits that selection could improve seed yield. Also, our observations and the data of Gautier and Everett (1979) indicate that it should be possible to get 2 seed harvests annually from globemallows.

\section{Forage Yield Study}

Except for a few $S$. grossulariifolia plants, the seedings at Curlew Valley did not establish and are not considered below. Possible reasons for the lack of stand development were insufficient moisture, competition from annual weeds, and soil crusting. These results support the recommendations of Wasser (1982), Stevens et al. (1985), and Horton (1989) to seed globemallows during fall or winter to take advantage of soil moisture early in the growing season.

Forb and total forage yields in Cache Valley differed significantly among the 6 treatments, but grass weights did not (Table 4).

Table 4. Season-long forage yields of 'Hycrest' crested wheatgrass-forb' mixtures in Cache Valley, Utah, 1985 to 1988.

\begin{tabular}{|c|c|c|c|c|c|c|}
\hline \multirow[b]{3}{*}{ Source } & \multicolumn{6}{|c|}{ Mixture component } \\
\hline & \multicolumn{2}{|c|}{ Forb } & \multicolumn{2}{|c|}{ Grass } & \multicolumn{2}{|c|}{ Total } \\
\hline & Mean & $\mathbf{S E}$ & Mean & SE & Mean & SE \\
\hline $\begin{array}{l}\text { Treatment } \\
\text { SPMU-accession } 1 \\
\text { SPMU-accession } 2 \\
\text { Mean of SPMU Accessions }\end{array}$ & $\begin{array}{l}76 \mathrm{a}^{2} \\
76 \mathrm{a} \\
76\end{array}$ & $\begin{array}{r}\cdots \\
21 \\
17 \\
12\end{array}$ & $\begin{array}{l}--g / n \\
89 a \\
96 a \\
93\end{array}$ & $\begin{array}{l}20 \\
22 \\
15\end{array}$ & $\begin{array}{l}165 \mathrm{a} \\
172 \mathrm{a} \\
169\end{array}$ & $\begin{array}{l}- \\
20 \\
17 \\
13\end{array}$ \\
\hline $\begin{array}{l}\text { SPGR-accession } 3 \\
\text { SPGR-accession } 4 \\
\text { SPGR-accession } 5 \\
\text { Mean of SPGR Accessions }\end{array}$ & $\begin{array}{l}62 \mathrm{a} \\
38 \mathrm{a} \\
43 \mathrm{a} \\
48\end{array}$ & $\begin{array}{r}16 \\
6 \\
21 \\
9\end{array}$ & $\begin{array}{c}98 \mathrm{a} \\
88 \mathrm{a} \\
112 \mathrm{a} \\
99\end{array}$ & $\begin{array}{l}21 \\
19 \\
18 \\
11\end{array}$ & $\begin{array}{l}160 \mathrm{a} \\
126 \mathrm{a} \\
155 \mathrm{a} \\
147\end{array}$ & $\begin{array}{l}23 \\
17 \\
12 \\
10\end{array}$ \\
\hline MESA-accession 6 & $389 \mathrm{~b}$ & 63 & $125 \mathrm{a}$ & 31 & $494 b$ & 83 \\
\hline $\begin{array}{l}\text { Year } \\
1985 \\
1986 \\
1987 \\
1988\end{array}$ & $\begin{array}{l}116 a b \\
86 a \\
101 a \\
140 b\end{array}$ & $\begin{array}{l}14 \\
36 \\
38 \\
49\end{array}$ & $\begin{array}{r}11 \mathrm{a} \\
107 \mathrm{~b} \\
197 \mathrm{c} \\
89 \mathrm{~b}\end{array}$ & $\begin{array}{r}2 \\
8 \\
15 \\
6\end{array}$ & $\begin{array}{l}127 \mathrm{a} \\
193 \mathrm{~b} \\
298 \mathrm{c} \\
229 \mathrm{~b}\end{array}$ & $\begin{array}{l}14 \\
39 \\
48 \\
50\end{array}$ \\
\hline
\end{tabular}

'Forbs were the globemallow (Sphaeralcea) or alfalfa (Medicago) component of a

mixture. differ significantly (LSD 06 ).

3SPMU =S. munroana; $\mathrm{SPGR}=S$. grossulariifolia; $\mathrm{MESA}=M$. sativa.

Forb and total forage yields were greater in the alfalfa than in the globemallow treatments. Average forb, grass, and total forage yield of the $S$. munroana treatments did not differ significantly from $S$. grossulariifolia treatments. Moreover, differences were not significant among the accessions within each of the globemallow species.

In terms of forage yield, our data indicate that there would be no advantage to using $S$. munroana over $S$. grossulariifolia in seedings. Alfalfa clearly produced more forage than globemallows. Our results also showed that crested wheatgrass does not respond differently to alfalfa versus globemallows.

Observations indicated that globemallows established more quickly in 1985 than either alfalfa or crested wheatgrass, but their density dropped dramatically in the ensuing years. Plots containing $S$. munroana had more relatively small plants, while plots containing $S$. grossulariifolia had fewer relatively large plants.

Year effects were significant for all mixture components (Table 4). Significantly less grass and total forage were produced in the

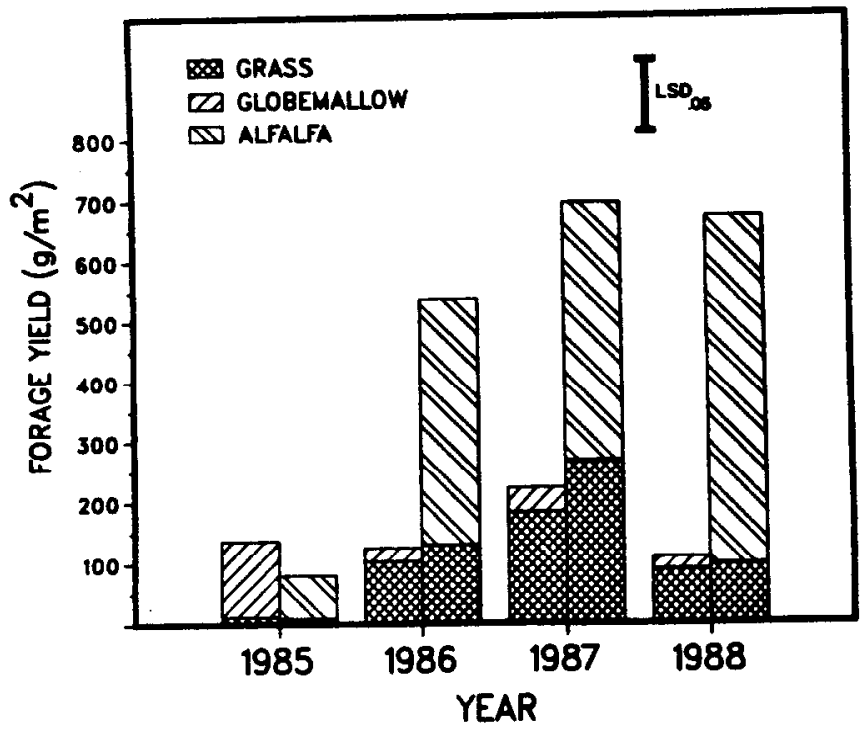

Fig. 1. Annual total forage yields of alfalfa and globemallow seeded with crested wheatgrass in Cache Valley, Utah.

establishment year (1985) than the average in the ensuing 3 years. However, forb forage yields did not differ when 1985 was contrasted with the average of the other 3 years. As discussed below, this was due to the different responses of globemallow and alfalfa. Second-year (1986) forage yields were significantly less than the average of the third (1987) and fourth (1988) year forage yields for the forb and total forage mixture components. We conclude that at least 2 years were required for these mixtures to fully establish. Forb forage yields in the wettest year (1986) were significantly less than in the driest year (1988). Grass and total forage yields did not differ when the wettest and driest years were contrasted. Possibly the forbs, which have taproots, were utilizing deep soil moisture in 1988 so they did not respond to lower rainfall with lower forage yields. When the establishment year was dropped from analyses the year effect remained significant for all mixture components. Significant forage treatment by year interactions for forb and total forage yields were probably caused by the relatively rapid development of the globemallows in the year of establishment versus the greater forage yield of the alfalfa in the more mature stand years (Fig. 1).

\section{Literature Cited}

Ackerman, T.L., E.M. Romney, A. Wallace, and J.E. Kinnear. 1980. Phenology of desert shrubs in southern Nye County, Nevada. Great Basin Naturalist Memoirs 4:4-23.

Gautier, C., and R. Everett. 1979. Fertilizing and clipping effects on seed capsule and forage production of orange globemallow. USDA Forest Serv. Int. Forest and Range Exp. Sta. Res. Note INT-25I.

Hewitt, G.B. 1980. Plant phenology as a guide in timing grasshopper control efforts on Montana rangeland. J. Range Manage. 33:297-299.

Horton, H. 1989. Planting guide for Utah. Utah State Univ. Coop. Ext. Serv. Ext. Circ. EC 433.

Howe, H.F., and S.J. Wright. 1986. Spatial pattern and mortality in the desert mallow (Sphaeralcea ambigua). Nat. Geog. Res. 2:491-499.

Jefferies, J.A.M. 1972. A revision of the genus Sphaeralcea (Malvaceae) for the state of Utah. M.S. Thesis, Brigham Young Univ., Provo, Utah.

Kearney, T.H. 1935. The North American species of Sphaeralcea subgenus Eusphaeralcea. Univ. California Pub. in Bot. 19:1-128.

Kramer, H.H., and R.L. Davis. 1949. The effect of stand and moisture content on computed yields of alfalfa. Agron. J. 41:470-473.

Pendery, B.M., and M.D. Rumbaugh. 1986. Globemallows: forbs for Utah rangelands. Utah Sci. 47:41-45.

Roth, T.E., J.L. Holechek, and M.Y. Hussain. 1987. Germination response of three globemallow species to chemical treatment. J. Range Manage. 40:173-175. 
Rumbaugh, M.D., R. R-C Wang, and B.M. Pendery. 1989. Chromosome numbers of western globemallow species. In: Agronomy Abstr., 81st Annu. Meeting, Amer. Soc. Agron. Amer. Soc. Agron., Madison, Wis. Sabo, D.G., G.V.Johnson, W.C. Martin, and E.F. Aldon. 1979. Germination requirements of 19 species of arid land plants. USDA Forest Serv. Rocky Mtn. Forest and Range Exp. Sta. Res. Pap. RM-210.

Stevens, R., N. Shaw, and C.G. Howard. 1985. Important nonleguminous forbs for Intermountain ranges. p. 210-220. In: Proc. Selected Papers Presented at the 38th Annu. Meeting Soc. Range Manage. Soc. Range Manage., Denver, Colo.
Uresk, D.W., and T. Yamamoto. 1986. Growth of forbs, shrubs, and trees on bentonite mine spoil under greenhouse conditions. J. Range Manage. 39:113-117.

Wasser, C.H. 1982. Ecology and culture of selected species useful in revegetating disturbed lands in the West. USDI Fish and Wildl. Serv. FWS/OBS-82/56.

Welch, S.L., N.D. Atwood, S. Goodrich, and L.C. Hizgins (eds.). 1987. A Utah Flora. Great Basin Naturalist Memoirs 9:421-424.

West, N.E. 1979. Survival patterns of major perennials in salt desert shrub communities of southwest Utah. J. Range Manage. 32:442-445.

Winer, B.J. 1962. Statistical principles in experimental design. McGrawHill, New York. 